\title{
Harbinger of storm: influence of Oliver Sacks on levodopa therapy in early 1970 s
}

\author{
Arauto da tempestade: a influência de Oliver Sacks sobre a terapia com levodopa no início \\ da década de 1970
}

Bruno Lopes dos Santos-Lobato ${ }^{1,2}$, Vitor Tumas ${ }^{1,2}$

\begin{abstract}
Most known by his literary ability, the words of the neurologist Oliver Sacks (1933-2015) also had an impact on scientific community about the role of levodopa on parkinsonisms. Different from the most authors and based on his experience described on the book "Awakenings", he had a pessimistic opinion about levodopa, which was related on many articles written by himself and colleagues in early 1970 s. We reviewed the scientific contribution of Oliver Sacks associated to levodopa therapy on parkinsonisms, and how he advised caution with its complications before the majority of physicians.
\end{abstract}

Keywords: Oliver Sacks, Parkinson's disease, levodopa, dyskinesias.

RESUMO

Mais conhecido por sua habilidade literária, as palavras do neurologista Oliver Sacks (1933-2015) também tiveram um impacto sobre a comunidade científica a respeito do uso de levodopa nos parkinsonismos. Diferente da maioria dos autores e baseado em sua experiência única descrita no livro "Tempo de Despertar", ele tinha uma opinião mais pessimista sobre a levodopa, que ficou relatada em uma série de artigos publicados por ele e colaboradores no início da década de 1970. Revisaremos a contribuição científica de Oliver Sacks referente ao tratamento dos parkinsonismos com levodopa, e como advertiu a cautela com as complicações decorrentes desta medicação antes da maioria dos médicos.

Palavras-chave: Oliver Sacks, doença de Parkinson, levodopa, discinesias.

Recently, we have lost Oliver Sacks (1933-2015), one of the most popular neurologists in the last decades, mainly due his fictional books which merge neurological practice and human experience, as "Migraine", "Awakenings" and "The Man Who Mistook His Wife for a Hat" (Figure). However, his role on the beginning of levodopa therapy in parkinsonian syndromes is poorly known, and few people remember that he and his colleagues had become pessimistic about the clinical utility of levodopa. Our aim is to review Sacks' scientific texts associated with levodopa in the early 1970s, and his counterpoint between medical opinions about this treatment.

\section{A NEW ERA BEGINS}

After the discovery of dopamine by Arvid Carlsson and its depletion in striatum of patients with Parkinson's disease (PD) by Oleh Hornykiewicz, several investigators started a race to achieve a treatment for parkinsonian syndromes using levodopa, but all have failed. In 1967, George Cotzias and colleagues described the use of dextro-levodopa in parkinsonisms, obtaining excellent results on motor symptoms, which were confirmed in 1969 by a new study using levodopa ${ }^{1}$. Also in 1969, Donald Calne and Melvin Yahr confirmed levodopa improved bradykinesia, rigidity, tremor and oculogyric crises in patients with postencephalitic and idiopathic parkinsonism in two different studies ${ }^{2,3}$.

\section{SACKS AND THE SUMMER OF 1969}

Influenced by the recent works of Cotzias and Calne, Oliver Sacks and his colleagues started a placebo-controlled trial, in 1969, using levodopa in patients with postencephalitic parkinsonism at Beth Abraham Hospital (New York). Initially, Sacks' patients also had a dramatic improvement

${ }^{1}$ Universidade de São Paulo, Faculdade de Medicina da Ribeirão Preto, Departamento de Neurociências e Ciências do Comportamento, Ribeirão Preto SP, Brasil; Universidade de São Paulo, Núcleo de Apoio à Pesquisa em Neurociência Aplicada, Ribeirão Preto SP, Brasil.

Correspondence: Bruno Lopes dos Santos-Lobato; Departamento de Neurociências e Ciências do Comportamento; Av. Bandeirantes, 3900; $14049-900$ Ribeirão Preto SP, Brasil; E-mail: bruls4@usp.br

Conflict of interest: There is no conflict of interest to declare.

Received 12 November 2015; Received in final form 23 March 2016; Accepted 18 May 2016 


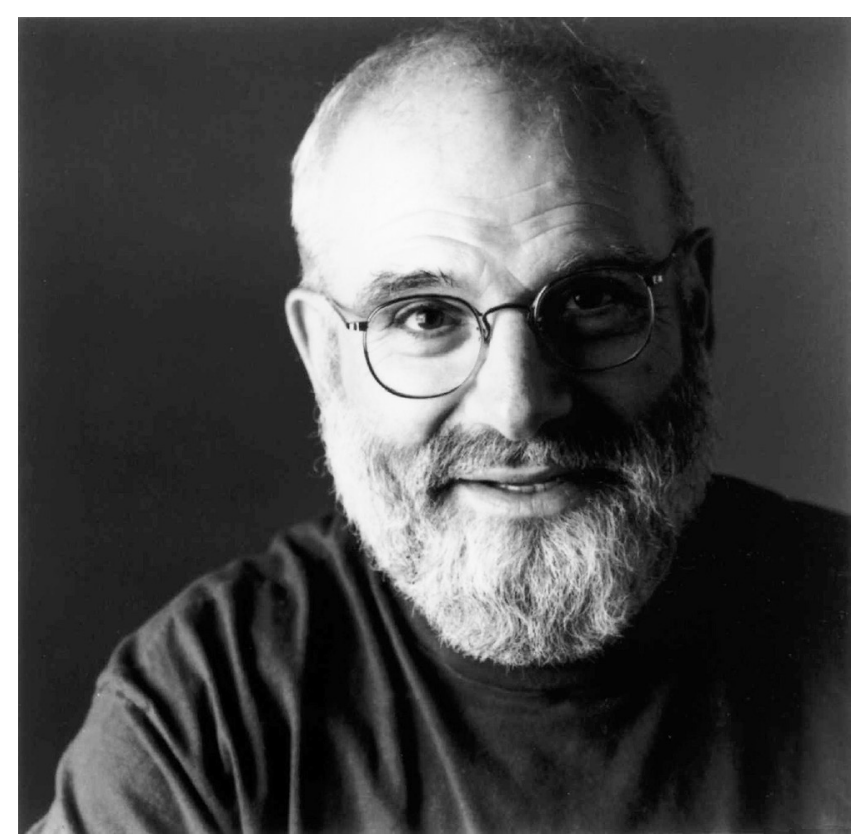

Figure. Oliver Sacks.

in parkinsonism, but the following chaotic adverse effects affected negatively the young neurologist: the patients developed severe dyskinesias and profound behavioral modifications, as aggressive outbursts, social disinhibition, hallucinations and delusions ${ }^{4}$.

These symptoms were already previously described, but Cotzias and Calne only subtly cited these disabling effects, without further discussion about their impact on patients. Oliver Sacks and his colleagues had a different stance on levodopa therapy, more pessimist, published in a series of articles in 1970.

\section{DESCRIBING THE PROBLEM}

During 1970, Sacks published five articles, "letter to editor", in Lancet and JAMA Journals. In May, he described some adverse effects of levodopa, mainly the "respiratory crises": attacks of gasping and breath holding, asymmetrical movement of the two sides of the chest and reversal of inspiratory and expiratory phases. According the authors, these crises were specific of postencephalitic parkinsonism ${ }^{5}$. Probably, this was the first description of respiratory dyskinesias induced by levodopa.

In June, Sacks described three patients with PD and dementia, in which levodopa caused a marked cognitive worsening, and suggested that the medication should be administered carefully in patients with dementia ${ }^{6}$. In the same month, he related the case of a 63-years old woman with postencephalitic parkinsonism which experienced the onset of psychomotor excitement associated with forced reminiscence and nostalgia of middle and late 1920s, as well as hallucinations and hypersexuality, after levodopa administration.
These symptoms urged a reduction of dosage, with total disappearance of these mental disturbances ${ }^{7}$.

In July, he focused on levodopa efficacy on oculogyric crises in his patients: disagreeing with Calne (which described good efficacy of levodopa on this symptom), Sacks noticed the medication did not prevent recurrence of oculogyric crises and could induce it ${ }^{8}$.

In September, Sacks published an impactful letter in JAMA, systematizing all adverse effects of levodopa observed in his 60 parkinsonian patients. Problems arising from the restoration of mobility, several adverse reactions associated to the use and withdrawal of levodopa, and emotional issues involving patients and families were insufficiently stressed. The authors highlighted levodopa could generate unusual complexities, and these effects were inadequately discussed in literature; therefore, they suggested "reservations about the release of the drug at this time" for clinical use9.

Years later, Sacks said the scientific community read with joyful interest his writing about levodopa, until September 1970 letter. After this, he received a harsh criticism, accusing him being "against levodopa" and against the great hope motivated by the medication efficacy. Thus, he decided to publish the results of his clinical trial in an "orthodox" format ("full of statistics and figures and tables and graphs"), and all journals rejected his submissions, "as if there were something intolerable in what I had written",

In 1972, he published, in an "orthodox" format, a description of adverse effects of levodopa in his patients with PD and dementia, relating all these individuals developed "chorea, akinesia, delirious psychosis or stupor/coma". These reactions occurred in a lesser severity in patients with PD without dementia. Sacks and his colleagues reaffirmed the caution to prescribe levodopa, and contraindicated its use on demented patients ${ }^{11}$.

\section{CONSEQUENCES}

After this article in 1972, Sacks reduced his publications on scientific journals. He explained that he prioritized a more "holistic" description ("human, scientific, existential, philosophical") of neurological experience, using a romantic and phenomenological style. In 1973, he published his book "Awakenings", where the stories of his postencephalitic parkinsonian patients treated with levodopa in Beth Abraham Hospital were told, and became a world-renowned writer ${ }^{4,10}$.

Since then, levodopa had become the main treatment of many types of parkinsonism. After its release to clinical use, physicians around the world could testify the complex management and the motor and non-motor complications related to the drug, as Sacks had warned. The susceptibility of demented patients to psychotic symptoms induced by high doses of levodopa was also recognized; Sacks and his colleagues were the first to describe this relationship. 
But why did Oliver Sacks have this particular worrying about complications of levodopa, when other investigators did not care about it? Probably, his singular sense of compassion to his patients seems to explain why he saw problems when all desired solutions. He criticized the scientific trend to just observe diseases and sick persons as a naturalist does, and not as the physician must do: to see sick people as human beings ${ }^{4,10}$. As his whole life, Sacks looked to the persons, not only to diseases.

\section{References}

1. Cotzias GC, Van Woert MH, Schiffer LM. Aromatic amino acids and modification of parkinsonism. N Engl J Med. 1967;276(7):374-9. doi:10.1056/NEJM196702162760703

2. Calne DB, Stern GM, Laurence DR, Sharkey J, Armitage P. L-dopa in postencephalitic parkinsonism. Lancet. 1969;1(7598):744-6. doi:10.1016/S0140-6736(69)91751-6

3. Yahr MD, Duvoisin RC, Schear MJ, Barrett RE, Hoehn MM. Treatment of parkinsonism with levodopa. Arch Neurol. 1969;21(4):343-54. doi:10.1001/archneur.1969.00480160015001

4. Sacks O. Tempo de despertar. São Paulo: Companhia das Letras; 1997.

5. Sacks OW, Kohl M, Schartz W, Messeloff C. Side-effects of L-dopa in postencephalic parkinsonism. Lancet. 1970;1(7654):1006. doi:10.1016/S0140-6736(70)91137-2
6. Sacks OW, Messeloff C, Schartz W, Goldfarb A, Kohl M. Effects of L-dopa in patients with dementia. Lancet. 1970;1(7658):1231. doi:10.1016/S0140-6736(70)91820-9

7. Sacks OW, Kohl M. Incontinent nostalgia induced by L-Dopa. Lancet. 1970;1(7661):1394. doi:10.1016/S0140-6736(70)91297-3

8. Sacks OW, Kohl M. L-dopa and oculogyric crises. Lancet. 1970;1(7665):215-6. doi:10.1016/S0140-6736(70)92572-9

9. Sacks OW, Messeloff CR, Schwartz WF. Long-term effects of levodopa in the severely disabled patient. JAMA. 1970;213(13):2270. doi:10.1001/jama.1970.03170390060017

10. Sacks O. The origin of “Awakenings". Br Med J (Clin Res Ed). 1983;287(6409):1968-9. doi:10.1136/bmj.287.6409.1968

11. Sacks OW, Kohl MS, Messeloff CR, Schwartz WF. Effects of levodopa in Parkinsonian patients with dementia. Neurology. 1972;22(5):516-9. doi:10.1212/WNL.22.5.516 